\title{
How I learn to love data
}

\author{
Ho Manh Toan
}

AISDL

Hanoi, 10-11-2020

During my first year as a researcher, I was overwhelmed with the complexity of statistics. What is regression? What is ordinary least squares? I received my first training in statistics in my undergraduate years. Little did I know that this subject would be a pinnacle in my life. Then, right after graduation, I started working as a researcher, started writing papers, and started learning about statistics.

To make the work more challenging, I have learned on the job with a series of papers and projects. At first, collecting data on a daily basis helped to provide a sense of understanding [1]. Then, I learned how to write the methods section. Step by step, the results section was the next. And finally, the whole article.

Interestingly, my first article was a qualitative study of the Vietnamese art market [2]. In this article, I applied the knowledge from my previous data collection work to the organization of the qualitative data in this article. Eventually, 35 cases with their characteristics were summarized in an Excel table.

Later on, I stumbled upon Bayesian statistics $[3,4]$. While Bayesian statistics certainly help in exploring the probabilistic trends, the collaborative efforts to turn folktales and pictures of ancient houses into data tables [5, 6, 7] opened up a whole new mindset on data.

Before any statistical investigation, collecting data is always the first step. Through this process, I have a deeper understanding of the data structure and the issue. The knowledge is useful in the data analysis. Moreover, especially in social sciences, a data point often comes with an interesting story. Knowing the story behind your data will help to make the discussion more humane. Fortunately, before I know more about statistics, I know about data.

\section{References}

[1] Vuong QH, La VP, Vuong TT, Ho MT, Nguyen THK, Nguyen TVH, Pham HH, Ho MT. (2018). An open database of productivity in Vietnam's social sciences and humanities for public use. Scientific Data 5: 180188. https://doi.org/10.1038/sdata.2018.188

[2] Vuong QH, Ho MT, Nguyen HKT, Vuong TT, Tran K, Ho MT. (2018). “Paintings Can Be Forged, But Not Feeling": Vietnamese Art-Market, Fraud, and Value. Arts 7(4), 62. https://doi.org/10.3390/arts7040062. 
[3] Vuong QH, La VP, Nguyen MH, Ho MT, Tran T, Ho MT. (2020). Bayesian analysis for social data: A step-by-step protocol and interpretation. MethodsX 7:100924. doi: 10.1016/j.mex.2020.100924.

[4] Vuong QH, La VP, Nguyen MH, Ho MT, Ho MT, Mantello P. (2020). Improving Bayesian statistics understanding in the age of Big Data with the bayesvl $\mathrm{R}$ package. Software Impacts 4:100016. https://doi.org/10.1016/j.simpa.2020.100016.

[5] Vuong QH, Bui QK, La VP, Vuong TT, Ho TM, Nguyen HKT, Nguyen NH, Nghiem PKC, Ho MT. (2019). Cultural evolution in Vietnam's early 20th century: a Bayesian networks analysis of Hanoi Franco-Chinese house designs. Social Sciences \& Humanities Open, 1(1), 100001; doi: 10.1016/j.ssaho.2019.100001

[6] Vuong QH, La VP, Vuong TT, Nguyen VH, Ho MT, Nguyen THK, Bui QK, Ho MT. (2018). Cultural additivity: Behavioural insights from the interaction of Confucianism, Buddhism, and Taoism in folktales. Palgrave Communications, 4, 143. https://doi.org/10.1057/s41599-018-0189-2.

[7] Vuong QH, Nguyen HKT, Ho MT, La VP, Vuong TT, Tran T, Hoang KL, Vu TH, Hoang PH, Nguyen MH, Ho MT. (2020). On how religions could accidentally incite lies and violence: Folktales as a cultural transmitter. Palgrave Communications 6:82; doi:10.1057/s41599-020-0442-3. 